is qualitatively similar to that found for colicines $K$ and $V$ obtained from strains of $E$. coli $i^{11,16}$ and of an uncharacterized colicine obtained from $E$. coli 710 (ref. 17). However, colicine $A$ contains considerably more protein and less carbohydrate than do these colicines.

This work was supported by a grant from the U.S. Public Health Service and the National Science Foundation.

G. T. BARRY

D. L. Everhari

M. Graham

University of Tennessee Memorial Research Center, Knoxville.

${ }^{1}$ Gratia, A., C.R. Soc. Biol., 93, 1040 (1925)

${ }^{2}$ Fredericq, P., Rev. Belge. Pathol. Med. Exp., 19, Supp. iv (1948).

${ }^{3}$ Jacob, F., Ann. Inst. Pasteur, 86, 149 (1954).

Vérnon, M., Ann. Inst. Pasteur, 100, Supp. 6, 16 (1961). Hamon, Y., Vérnon, M., and Péron, Y., ibid., 101, 738 (1961).

${ }^{5}$ Brubaker, R. R., and Surgalla, M. J., J. Bact., 82, 940 (1961).

Ivanovics, G., and Alfoldi, L., J. Gen. Microbiol., 16, 522 (1957).

"Anacker, R. L., and Ordal, E. J., J. Bact., 78, 33 (1959).

${ }^{8}$ De Klerk, H. C., and Coetzee, J. N., Nature, 192, 340 (1961).

Jacob, F., Siminovitch, L., and Wollman, E. L., Ann. Inst. Pasteur, 83, 295 (1952).

${ }^{10}$ Lwoff, A., Siminoviteh, L., and Kjeldgaard, N., Ann. Inst. Pasteur, 79, $815(1950)$.

${ }^{11}$ Goebel, W. F., and Barry, G. T., J. Exp. Med., 107, 185 (1958)

${ }^{12}$ Goebel, W. F., Barry, G. T., and Shedlovsky, T., J. Exp. Med., 103, 135 (1956)

13 Barry, G. T., and Pierce, F., J. Biochem. Microbiol. Tech. and Eng., 1, 297
(1959).

Dische, Z

${ }_{15}$ Barry, G. T., Nature, 183, 117 (1959)

${ }^{16}$ Hutton, J. J., and Goebel, W. F., J. Gen. Physiol., 45, Supp. 1, 125 (1962).

${ }^{17}$ Nïske, R., Hösel, G., Venner, H., and Zinner, H., Biochem. Z., 329, 346 $(1957)$.

\section{Growth Factors for Selenomonas ruminantium}

THE effect of volatile fatty acids as growth factors for rumen bacteria is well known, but in most cases so far reported the branched-chain fatty acids, sometimes in combination with straight chain acids, have been found to be most effective. In a recent paper, Bryant and Robinson ${ }^{1}$ mentioned that their results showed the importance of acetate in the nutrition of many species of bovine rumen bacteria. However, their strains of $S$. ruminantium varied in the response to volatile fatty acids, a mixture of such acids other than acetate, propionate and $n$-butyrate boing stimulatory or essential, while acetate was stimulatory to two strains, but only in the absence of casein hydrolysate. Hobson and Mann ${ }^{2}$ earlier reported that acetate stimulated the growth of isolates of sheep rumen $S$. ruminantium and some further observations are described. in this communication.

The organism examined in detail was strain 6 of the isolates described by Hobson and Mann and it was routinely grown in the casein hydrolysate- (Difco 'Casitone'), yeast extract-, ammonia-containing medium similar to medium 14 (ref. 2), but with 1 per cent glycerol as carbohydrate. Further tests showed that the organism did not utilize ammonia in this medium and would not grow in a medium containing ammonia as main nitrogen source with vitamins added, with or without the addition of acetate, and that more than 0.75 per cent 'Casitone' was needed for good growth, although the concentration of yeast extract used in the foregoing medium could be decreased in the presence of the normal 1.5 per cent 'Casitone'. For the following tests the routine medium (above) was used with volatile fatty acids added as sodium salts. The rate of growth and maximum growth were determined in arbitrary units from the optical densities of the cultures. In the basal medium maximum growth was usually attained after about $26 \mathrm{~h}$, but readings were continued to $50 \mathrm{~h}$. Acetate alone increased both the rate of growth and the final density (maximum increase was from 13 to 19 units) at concentrations of from 0.03 to to $0.10 \mathrm{~m}$.equiv. $/ \mathrm{ml}$. Above this concentration stimulation was less and above $0.20 \mathrm{~m}$.equiv. $/ \mathrm{ml}$. maximum growth was depressed below that in the basal medium.
Propionate in similar concentrations slowed down growth, but did not greatly affect the maximum density (attained at $40-50 \mathrm{~h}$ ). $n$-Butyrate in similar concentrations was slightly inhibitory, culture density never attaining that in the basal medium. iso-Butyrate and $n$ - or iso-valerate were definitely inhibitory. Mixtures of straight-ehain (higher than propionic), or straightand branched-chain acids were also inhibitory. At the lowest concentrations equimolecular mixtures of acetic and propionic acids had much the same stimulatory effect as acetic alone at a concentration equivalent to that of the mixture; at higher concentrations the propionate depressed the stimulation of acetate and slowed down growth markedly. Similar mixtures of acetate and butyrate had the same effect, and mixtures of acetic and other higher acids were inhibitory or stimulated less than acetic alone. Pyruvate at a concentration of 0.06 m.equiv. $/ \mathrm{ml}$. in the medium without glycerol did not increase the slight growth always found in this medium without carbohydrate. A similar concentration of pyruvate in the presence of glycerol caused a long lag (more than $24 \mathrm{~h}$ ) before growth started, but growth was then rapid and the final culture density was about twice that of the medium with glycerol alone.

This sheep rumen strain of $S$. ruminantium differs from many rumen bacteria and the bovine $S$. ruminantium strains of Bryant and Robinson in not utilizing ammonia and requiring amino-acids for growth. Also, acetate is stimulatory for growth even in the presence of a casein hydrolysate, and none of the other volatile fatty acids is stimulatory, while some are inhibitory. It would seem that the lack of effect of acetate in the presence of casein hydrolysate found by Bryant and Robinson was due to acetate in their casein hydrolysate, as they suggested, and, not to acetate-replacing factors. In our own experiments the basal medium contained no volatile acid. An effect of pyruvate similar to that noted here has been found with certain other bacteria, for example, Strep. salivarius ${ }^{3}$.

P. N. HoBson

S. O. MANN

Rowett Research Institute, W. Sмrтн

Bueksburn, Aberdeen.

${ }^{1}$ Bryant, M. P., and Robinson, I. M., J. Bact., 84, 605 (1962),

${ }^{2}$ Hobson, P. N., and Mann, S. O., J. Gen. Mierobiol., 25, 227 (1961). ${ }^{3}$ Smiley, K. L., Niven, C. F., and Sherman, J. M., J. Bact., 45, 445 (1943).

\section{Site of Gram Stain in Cells of Gram-positive Micro-organisms}

THE direct observation of the site of Gram stain in cells of micro-organisms could not be attempted before the ultra-thin section technique became available. However, to obtain a suitable section, specimens have to be dehydrated either by alcohol or by a water-miscible resin (for example, 'Durcupan'), prior to the embedding. Both techniques in their normal applications remove sufficiently the stain from Gram-positive organisms to make them unsuitable for topographic investigation of the site of Gram stain.

The modified Gram stain technique ${ }^{1}$ allows one to carry out the differentiation and dehydration in iodinated alcohol with little removal of the stain from Gram-positive organisms. A final bath of $30 \mathrm{~min}$ in absolute alcohol is enough to remove the residual iodine and the normal embedding methods with epoxyl-resin can then be applied with only small further loss of the stain from the cell.

Gram-positive cells during embedding were examined by light microseope and were found that they remain Gram-positive up to, and including, the final stage.

Ultra-thin sections were then obtained by the normal sectioning method. The ribbon was picked up by the tip of a small broken piece of microscope coverglass and then mounted in water or in immersion oil. The examina. tion was made with light and phase microscope. 